\title{
A Comparison of Performances of Turbines for Wave Power Conversion
}

\author{
T. SETOGUCHI *, M. TAKAO and K. KANEKO \\ Department of Mechanical Engineering, Saga University, 1 Honjo-machi, Saga-shi, Saga, 840-8502 Japan \\ (Received 19 August 1997; In final form 28 July 1998)
}

\begin{abstract}
A number of self-rectifying air turbines for wave power conversion have been proposed so far. This paper shows the comparison of the performances of all these turbines proposed for use in the near future. As a result, the impulse turbine with self-pitch-controlled guide vanes is found to have the best performance.
\end{abstract}

Keywords: Wells turbine, Impulse turbine, Wave power conversion, Natural energy, Ocean energy, Fluid machinery

\section{INTRODUCTION}

A Wells turbine is a self-rectifying air turbine which is expected to be widely used in wave energy devices with oscillating water-air-column. There are many reports which describe the performance of the Wells turbine both at starting and at running conditions (Inoue et al., 1988; Raghunathan and Tan, 1982). According to these results, the Wells turbine has inherent disadvantages: lower efficiency, poorer starting and higher noise level in comparison with conventional turbines. In order to overcome these weak points, many kinds of turbines have been proposed (Takao and Setoguchi, 1996; Inoue et al., 1989; Setoguchi et al., 1990; 1996). However, the comparison of characteristics of all these has not yet been made so far.
The objective of this paper is to compare the performances of turbines, those that could be used for wave power conversion in the near future. The types of turbine included in the paper are as follows: (a) Wells turbine (Inoue et al., 1988); (b) Wells turbine with guide vanes (Takao and Setoguchi, 1996); (c) Turbine with self-pitch-controlled blades (Inoue et al., 1989); (d) Biplane Wells turbine with guide vanes (Setoguchi et al., 1990) and (e) Impulse turbine with self-pitch-controlled guide vanes (Setoguchi et al., 1996).

The present status of these turbines is as follows. The Wells turbine with guide vanes will be adopted for the project so-called "Mighty Whale" organized by JMSTEC, Japan (Miyazaki, 1993). The turbine with self-pitch-controlled blades is connected with the "Azores Pilot Plant" supported from the

* Corresponding author. 
JOULE II (Falcão et al., 1993), where the turbine has pitch-controlled blades. The project using the biplane Wells turbine is making progress in Islay, UK (Falcão et al., 1993), where the guide vanes are not used for the turbine. The impulse turbine with self-pitch-controlled guide vanes will be constructed by NIOT, India (Santhakumar, 1996).

\section{EXPERIMENTAL METHOD AND PROCEDURE}

The test rig consists of a large piston-cylinder, a settling chamber and a 300-mm-dia. test section with a bellmouthed entry and a diffuser exit (Fig. 1) (Inoue et al., 1988; 1989; Takao and Setoguchi,
1996). The turbine rotor with $v=0.7$ was placed at the center of the test section and tested at a constant rotational speed under steady flow conditions. The test Reynolds number was about $1.5 \times 10^{5}$ based on the relative inlet velocity and chord length of the rotor blade at mean radius. The performance was evaluated by $T, Q, \omega$ and $\Delta p$. The uncertainties in torque coefficient $C_{\mathrm{T}}$ and input coefficient $C_{\mathrm{A}}$ are $\pm 2 \%$, respectively.

The details of turbines adopted in the experiment are as follows: (a) Wells turbine (Fig. 2), NACA0020, $\mathrm{AR}=0.5, l_{\mathrm{r}}=90 \mathrm{~mm}$ and $\sigma_{\mathrm{rR}}=0.79$; (b) Wells turbine with guide vanes (Fig. 3), $\mathrm{NACA} 0020, \mathrm{AR}=0.5, l_{\mathrm{r}}=90 \mathrm{~mm}, \sigma_{\mathrm{rR}}=0.67$ and $\sigma_{\mathrm{gR}}=1.25$; (c) Turbine with self-pitch-controlled blades (Fig. 4), NACA0020, AR $=0.5, l_{\mathrm{r}}=90 \mathrm{~mm}$,

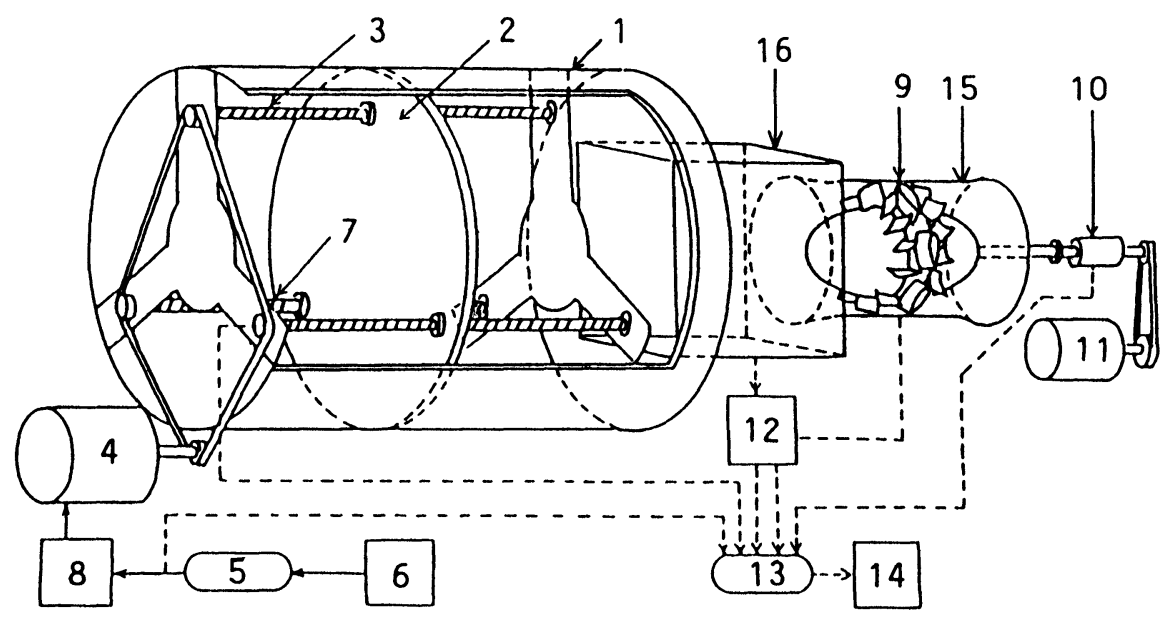

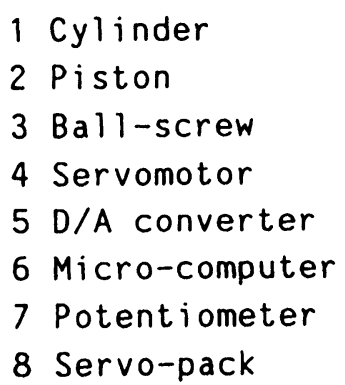

9 Turbine

10 Torque transducer

11 Servomotor-generator

12 Pressure transducer

$13 \mathrm{~A} / \mathrm{D}$ converter

14 Micro-computer

15 Test section

16 Settling chamber

FIGURE 1 Outline of experimental apparatus. 


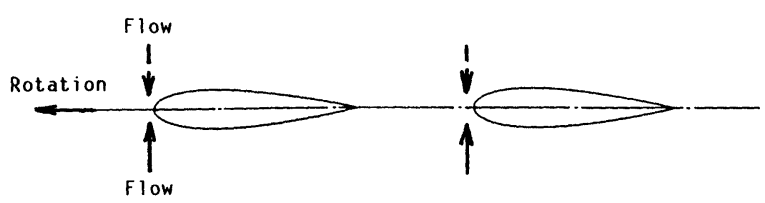

FIGURE 2 Wells turbine: Turbine (a).

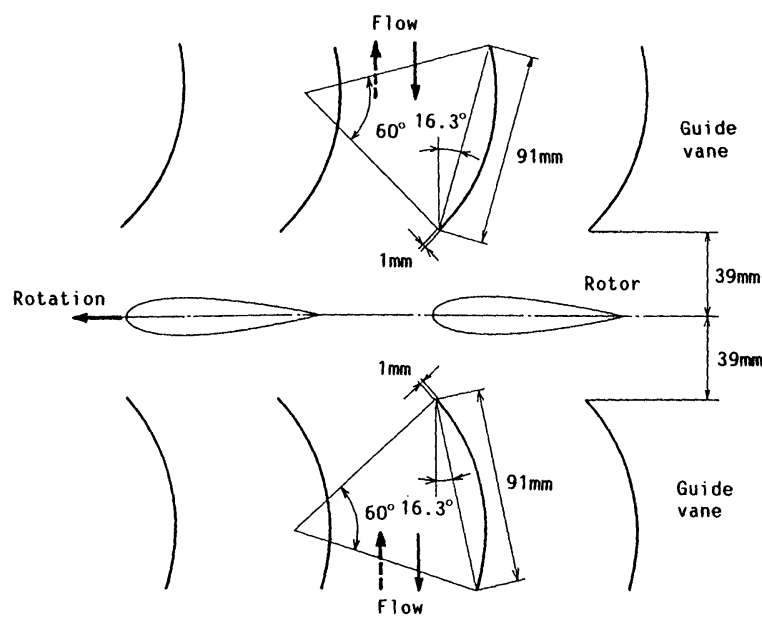

FIGURE 3 Wells turbine with guide vanes: Turbine (b).

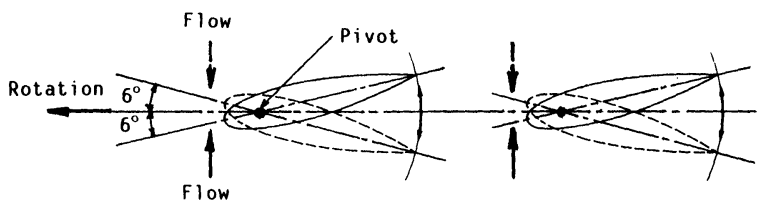

FIGURE 4 Turbine with self-pitch-controlled blades: Turbine (c)

$\sigma_{\mathrm{rR}}=0.67$ and preset angle of $6^{\circ} ;$ (d) Biplane Wells turbine with guide vanes (Fig. 5), NACA0020, $\mathrm{AR}=0.5, l_{\mathrm{r}}=90 \mathrm{~mm}, \sigma_{\mathrm{rR}}=0.45$ and $\sigma_{\mathrm{gR}}=1.25$ and (e) Impulse turbine with self-pitch-controlled guide vanes (Fig. 6), $t_{\mathrm{a}} / S_{\mathrm{r}}=0.4, l_{\mathrm{r}}=54 \mathrm{~mm}, \gamma=60^{\circ}$, $a / b=3, \sigma_{\mathrm{rR}}=2.02, \sigma_{\mathrm{gR}}=2.27, \theta_{1}=17^{\circ}, \theta_{2}=72.5^{\circ}$ and $\lambda=-7.5^{\circ}$. Note here that the geometries considered for these turbines are the ones found to be most promising in the previous studies (Inoue et al., 1988; 1989; Takao and Setoguchi, 1996; Setoguchi et al., 1990; 1996). Furthermore, all of them can start (Inoue et al., 1986) by themselves. Hereafter we will call the turbines shown in Figs. 2-6 as turbines (a)-(e), respectively.

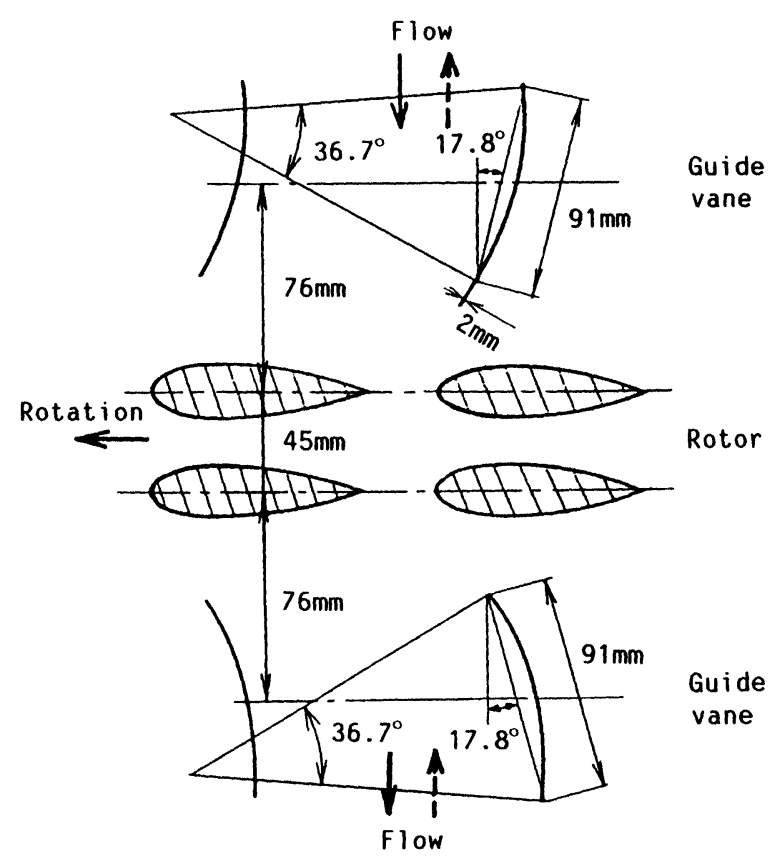

FIGURE 5 Biplane Wells turbine with guide vanes: Turbine (d).

\section{EXPERIMENTAL RESULTS AND DISCUSSIONS}

The performance of the turbine is represented by torque coefficient $C_{\mathrm{T}}$ and input coefficient $C_{\mathrm{A}}$. The variations of $C_{\mathrm{T}}$ and $C_{\mathrm{A}}$ are shown against $\phi$ in Fig. 7. It is clear that the decrease in $C_{\mathrm{T}}$ due to the stall is observed in the cases of turbines (a)-(d), and the largest flow coefficient at stall point is obtained by turbine (c). On the other hand, there exits no abrupt drop in $C_{\mathrm{T}}$ for turbine (e). This is because there is no stall for the impulse turbine, and means that the starting and transitional characteristics to running condition are improved in the case of turbine (e). Figure 7(b) shows that the $C_{\mathrm{A}}$ is larger in the case of turbines (a) and (b) than those of turbines (c)-(e) over the whole range of $\phi$. This means that the thrust generated by the turbine becomes large for the turbines (a) and (b).

In order to compare the performances of the turbines under unsteady flow conditions, the numerical calculation was carried out. The equation of motion for the rotating system of a turbine 
(a)

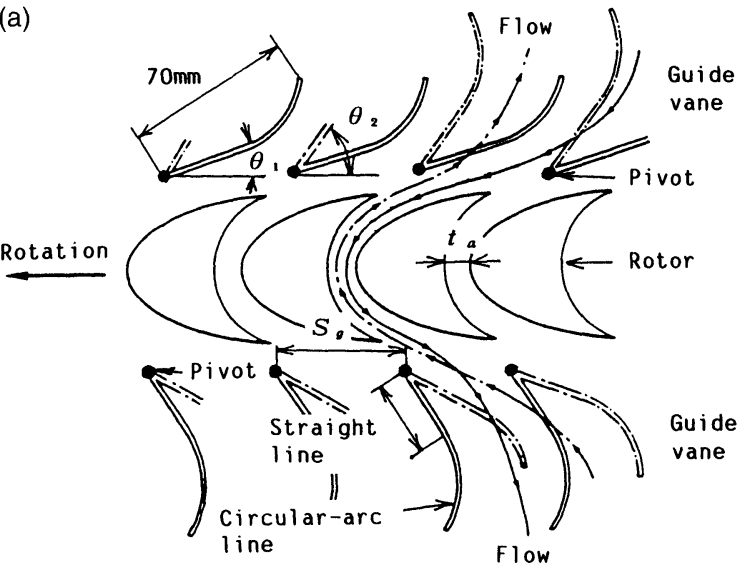

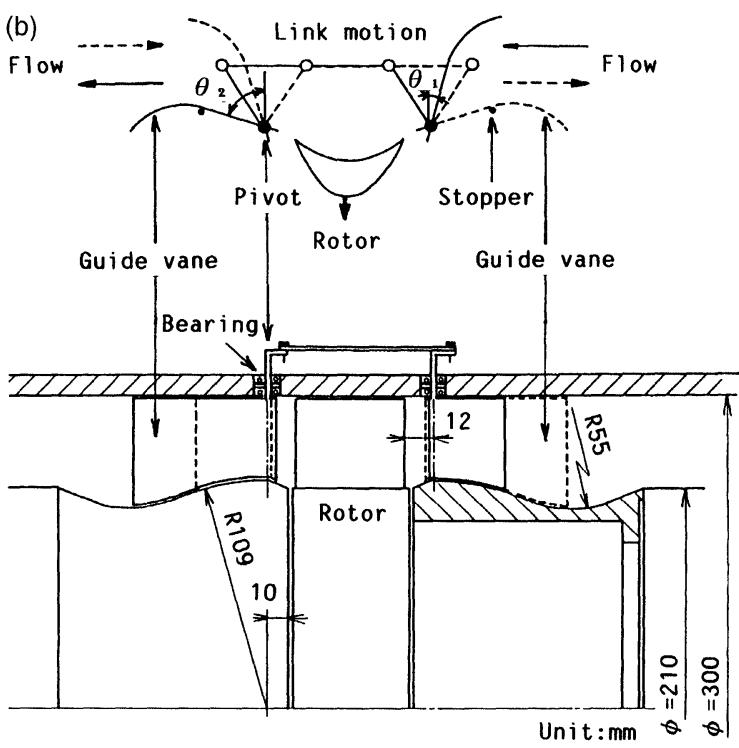

FIGURE 6 Impulse turbine with self-pitch-controlled guide vanes connected by links: Turbine (e): (a) schematic view; (b) details of turbine.
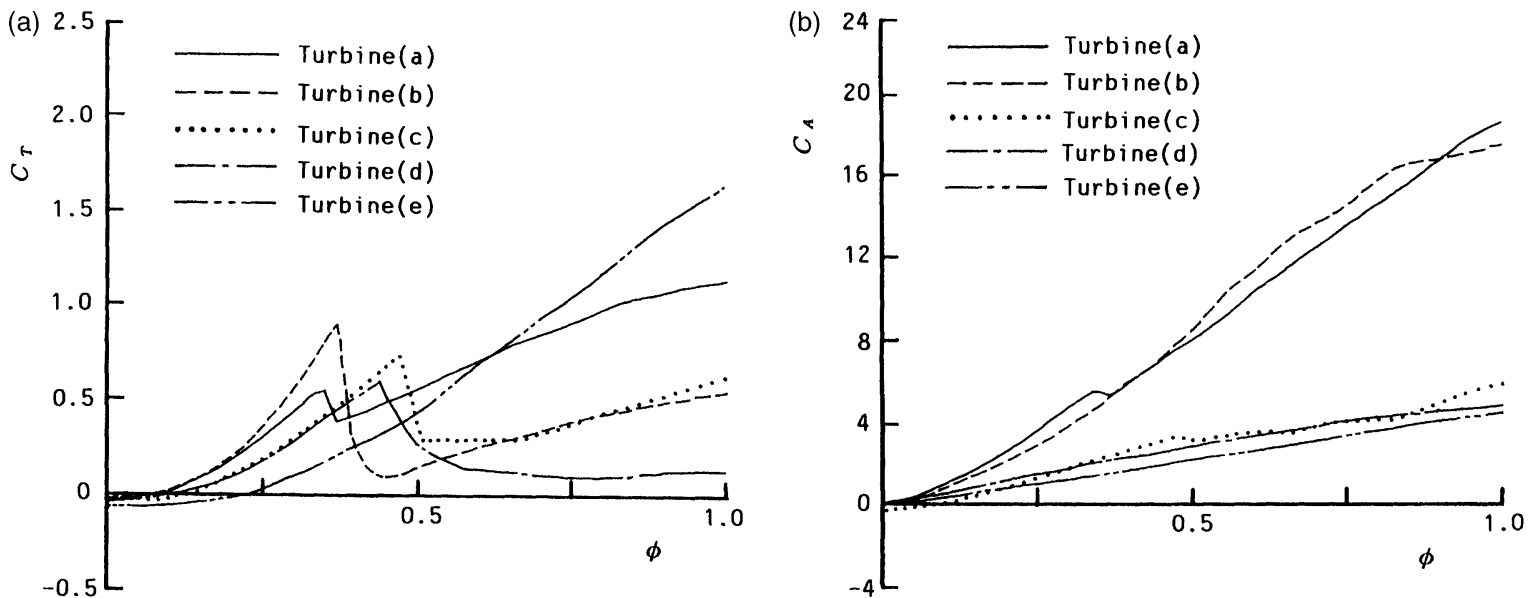

FIGURE 7 Turbine characteristics under steady condition: (a) torque coefficient; (b) input coefficient.

in a sinusoidally reciprocating flow is written in a nondimensional form (Inoue et al., 1986) as follows:

$$
\begin{aligned}
& S^{2} X_{\mathrm{I}}\left(\mathrm{d} \omega^{*} / \mathrm{d} t^{*}\right)+X_{\mathrm{L}} \\
& \quad=2 C_{\mathrm{T}} \sigma_{\mathrm{rR}} \frac{1-\nu}{1+\nu}\left\{\sin ^{2}\left(2 \pi t^{*}\right)+\frac{1}{\Phi^{2}}\right\} .
\end{aligned}
$$

Equation (1) can be solved numerically as an initial problem when $C_{\mathrm{T}}$ and a wave motion are given.
This gives the starting characteristics of the turbine at the beginning and the running characteristics in an asymptotic condition. When the solution is in the asymptotic condition, the turbine performance can be obtained by mean efficiency defined by:

$$
\bar{\eta}=\left(f \int_{0}^{1 / f} T \omega \mathrm{d} t\right) /\left(f \int_{0}^{1 / f} \Delta p Q \mathrm{~d} t\right) .
$$


In the calculation, the flow conditions are assumed to be quasi-steady. Furthermore it is assumed, for simplicity, that there is no delay in the behavior of rotor blades (Fig. 4) (Inoue et al., 1989) and guide vanes (Fig. 5) (Setoguchi et al., 1996), that is, they turn instantaneously to the required orientation corresponding to the flow direction.

Figure 8 presents the comparison of mean efficiency for the five turbines noted above. The efficiency of the impulse turbine (turbine (e)) is higher over the wider range of $\Phi$ in comparison with the Wells-type turbines.

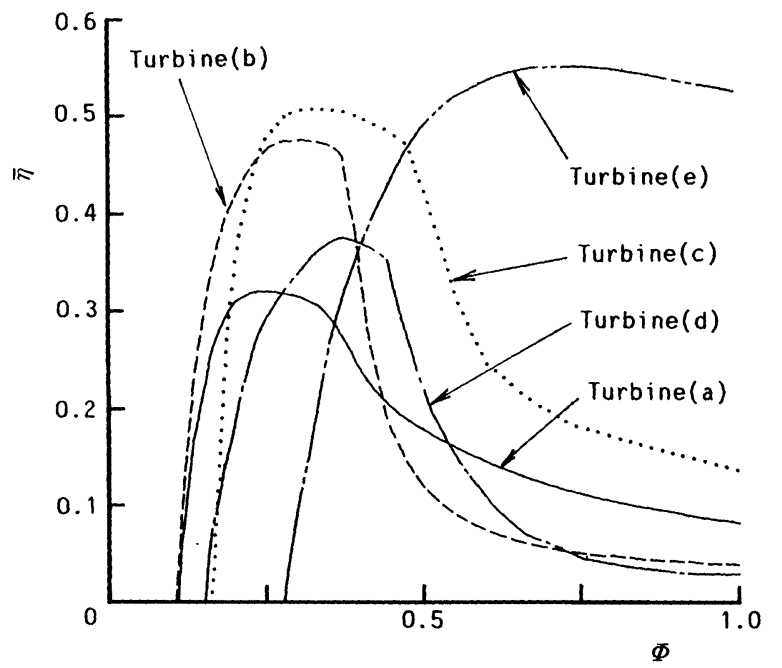

FIGURE 8 Comparison of mean efficiency.

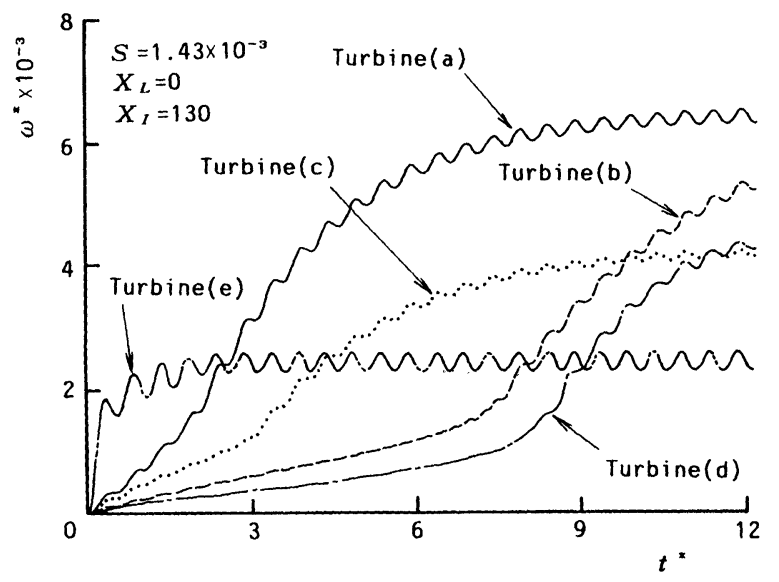

FIGURE 9 Comparison of starting characteristics.
The calculated starting characteristics for the five turbines are shown in Fig. 9. The turbine (e) can start in a very short time. Moreover, the rotating speed while in operation is much smaller than those of others. Therefore, it may be possible to design an excellent turbine due to low relative speed, which is desirable from the viewpoints of noise reduction and mechanical advantage.

\section{CONCLUDING REMARKS}

The self-pitch-rectifying air turbines for wave power conversion proposed so far were tested from a viewpoint of usefulness. As a result, the impulse turbine with self-pitch-controlled guide vanes is the recommended one.

\section{NOMENCLATURE}

$\begin{array}{ll}\text { AR } & \text { aspect ratio } \\ a, b & \text { radii of ellipse for impulse turbine rotor } \\ C_{\mathrm{A}} & \text { input coefficient }=\Delta p Q /\left(\rho h l_{\mathrm{r}} v_{\mathrm{a}} w_{1}^{2} z / 2\right) \\ C_{\mathrm{T}} & \text { torque coefficient }=T /\left(\rho h l_{\mathrm{r}} r_{\mathrm{R}} w_{1}^{2} z / 2\right) \\ f & \text { frequency of wave motion } \\ h & \text { blade height } \\ I & \text { moment of inertia of rotor } \\ l_{\mathrm{r}} & \text { chord length of rotor } \\ Q & \text { flow rate } \\ r_{\mathrm{R}} & \text { mean radius } \\ S & \text { nondimensional frequency }=f_{\mathrm{r}_{\mathrm{R}}} / V_{\mathrm{a}} \\ t & \text { time } \\ t_{\mathrm{a}} & \text { width of flow path } \\ t^{*} & \text { nondimensional time }=t f \\ T & \text { output torque } \\ T_{\mathrm{L}} & \text { loading torque } \\ U_{\mathrm{R}} & \text { circumferential velocity at } r_{\mathrm{R}} \\ v_{\mathrm{a}} & \text { axial velocity } \\ V_{\mathrm{a}} & \text { maximum value of } v_{\mathrm{a}} \\ w_{1} & \text { relative velocity at inlet } \\ X_{\mathrm{I}} & \text { nondimensional moment } \\ & \text { of inertia }=I /\left(\pi \rho r_{\mathrm{R}}^{5}\right) \\ X_{\mathrm{L}} & \text { nondimensional loading } \\ & \text { torque }=T_{\mathrm{L}} /\left(\pi \rho r_{\mathrm{R}}^{3} V_{\mathrm{a}}^{2}\right) \\ & \end{array}$


$z \quad$ number of blades

$\Delta p \quad$ total pressure drop across turbine

$\bar{\eta} \quad$ mean efficiency

$\theta_{1} \quad$ setting angle of upstream guide vane

$\theta_{2} \quad$ setting angle of downstream guide vane

$v \quad$ hub-to-tip ratio

$\lambda \quad$ sweep angle

$\rho \quad$ density of air

$\sigma_{\mathrm{gR}} \quad$ chord/space ratio of guide vane at $r_{\mathrm{R}}$

$\sigma_{\mathrm{rR}} \quad$ chord/space ratio of rotor at $r_{\mathrm{R}}$

$\phi \quad$ flow coefficient $=v_{\mathrm{a}} / U_{\mathrm{R}}$

$\Phi \quad$ flow coefficient $=V_{\mathrm{a}} / U_{\mathrm{R}}$

$\omega \quad$ angular velocity of rotor

$\omega^{*} \quad$ nondimensional angular velocity $=\omega / f$

\section{References}

Falcão, A.F.O., Whittaker, T.J.T. and Lewis, A.W. (1993) JOULE II Preliminary action: European pilot plant study, Proc. 1993 European Wave Energy Symp., pp. 247-257.

Inoue, M., Kaneko, K., Setoguchi, T. and Raghunathan, S. (1986) Simulation of starting characteristics of walls turbine,
Proc. AIAA/ASME 4th Fluid Mechanics, Plasma Dynamics and Laser Conf., No. AIAA-86-1122.

Inoue, M., Kaneko, K., Setoguchi, T. and Hamakawa, H. (1988) Studies on the wells turbine for wave energy generator, JSME Int'l. Journal, Ser. II, 31, 676-682.

Inoue, M., Kaneko, K., Setoguchi, T. and Hamakawa, H. (1989) Air turbine with self-pitch-controlled blades for wave power generator (estimation of performance by model testing), JSME Int'l. Journal, Ser. II, 32, 19-24.

Miyazaki, T. (1993) Utilization of coastal seas by floating wave energy device "Mighty Whale", Proc. 1993 European Wave Energy Symp., pp. 373-378.

Raghunathan, S. and Tan, C.P. (1982) Performance of wells turbine at starting, Journal of Energy, 6, 430-431.

Santhakumar, S. (1996) Report of workshop on turbine for ocean energy application, IIT Madras.

Setoguchi, T., Kaneko, K., Matsuki, E., Hamakawa, H. and Inoue, M. (1990) Some techniques to improve the performance of biplane wells turbine for wave power generator, Proc. Ist Pacific/Asia Offshore Mechanics Symp., Vol. 1, pp. 207-212.

Setoguchi, T., Kaneko, K., Taniyama, H., Maeda, H. and Inoue, M. (1996) Impulse turbine with self-pitch-controlled guide vanes for wave power conversion: guide vanes connected by links, Int'l. Journal of Offshore and Polar Eng., 6, 76-80.

Takao, M. and Setoguchi, T. (1996) Performance of wells turbine with guide vanes for wave energy conversion, Journal of Thermal Science, 5, 82-87. 


\section{ait \\ ENERGY MATERIALS}

M A N E Y publishing

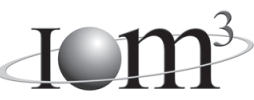

\section{Materials Science \& Engineering for Energy Systems}

Maney Publishing on behalf of the Institute of Materials, Minerals and Mining

The Institute of Materials, Minerals \& Mining

Economic and environmental factors are creating ever greater pressures for the efficient generation, transmission and use of energy. Materials developments are crucial to progress in all these areas: to innovation in design; to extending lifetime and maintenance intervals; and to successful operation in more demanding environments. Drawing together the broad community with interests in these areas, Energy Materials addresses materials needs in future energy generation, transmission, utilisation, conservation and storage. The journal covers thermal generation and gas turbines; renewable power (wind, wave, tidal, hydro, solar and geothermal); fuel cells (low and high temperature); materials issues relevant to biomass and biotechnology; nuclear power generation (fission and fusion); hydrogen generation and storage in the context of the 'hydrogen economy'; and the transmission and storage of the energy produced.

As well as publishing high-quality peer-reviewed research, Energy Materials promotes discussion of issues common to all sectors, through commissioned reviews and commentaries. The journal includes coverage of energy economics and policy, and broader social issues, since the political and legislative context influence research and investment decisions.

\section{CALL FOR PAPERS}

Contributions to the journal should be submitted online at http://ema.edmgr.com

To view the Notes for Contributors please visit: www.maney.co.uk/journals/notes/ema

Upon publication in 2006, this journal will be available via the Ingenta Connect journals service. To view free sample content online visit: www.ingentaconnect.com/content/maney

For further information please contact:

Maney Publishing UK

Tel: +44 (0)113 2497481 Fax: +44 (0)1132486983 Email: subscriptions@maney.co.uk

or

Maney Publishing North America

Tel (toll free): 8662975154 Fax: 6173546875 Email: maney@maneyusa.com

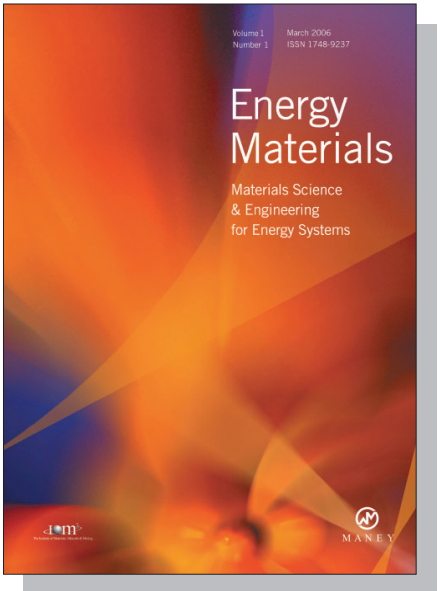

EDITORS

Dr Fujio Abe

NIMS, Japan

Dr John Hald, IPL-MPT, Technical University of Denmark, Denmark

Dr R Viswanathan, EPRI, USA

\section{SUBSCRIPTION INFORMATION}

Volume 1 (2006), 4 issues per year

Print ISSN: 1748-9237 Online ISSN: 1748-9245

Individual rate: $£ 76.00 / U S \$ 141.00$

Institutional rate: $£ 235.00 /$ US $\$ 435.00$

Online-only institutional rate: $£ 199.00 / U S \$ 367.00$

For special $\mathrm{IOM}^{3}$ member rates please email

subscriptions@maney.co.uk

\section{For further information or to subscribe online please visit www.maney.co.uk}



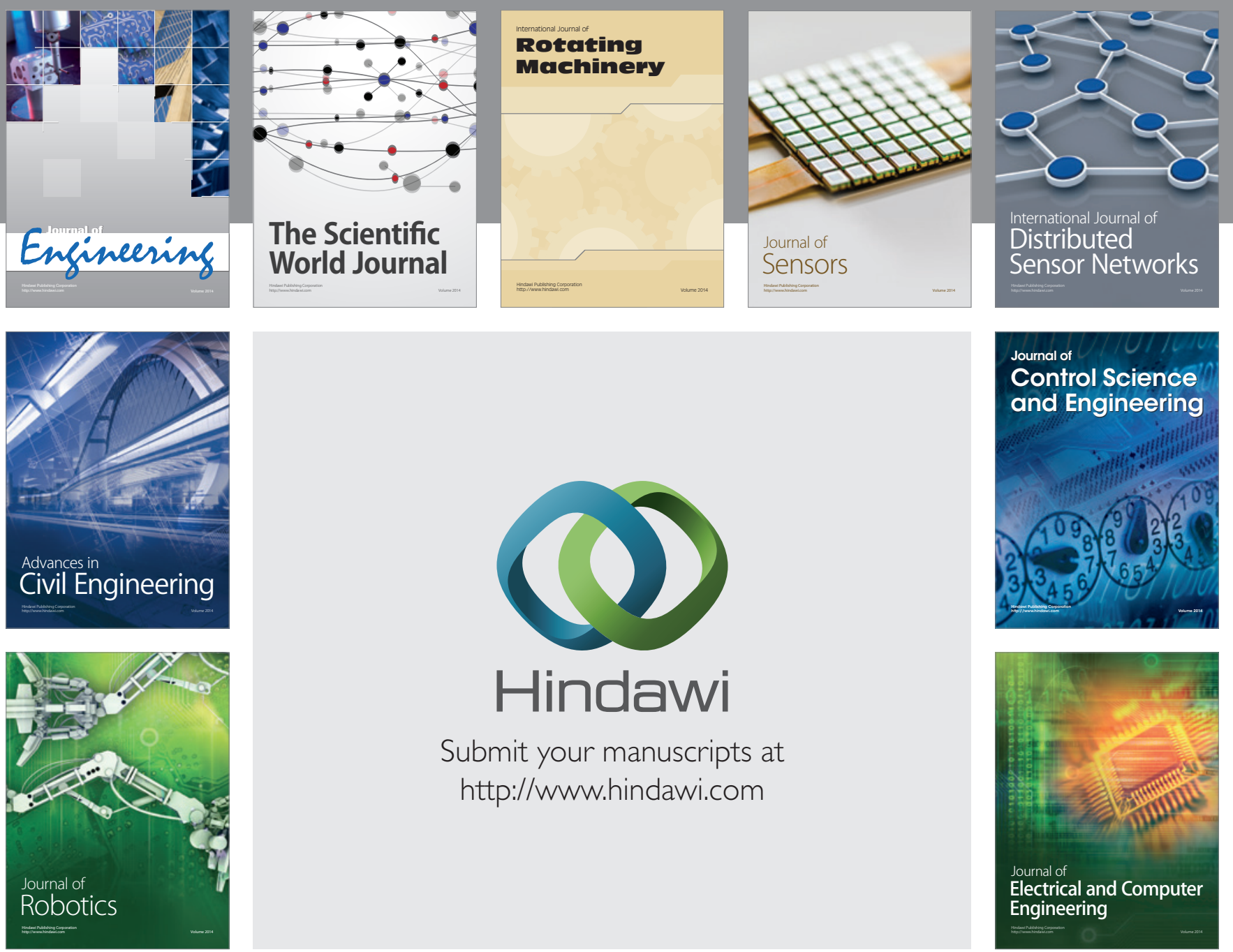

Submit your manuscripts at

http://www.hindawi.com
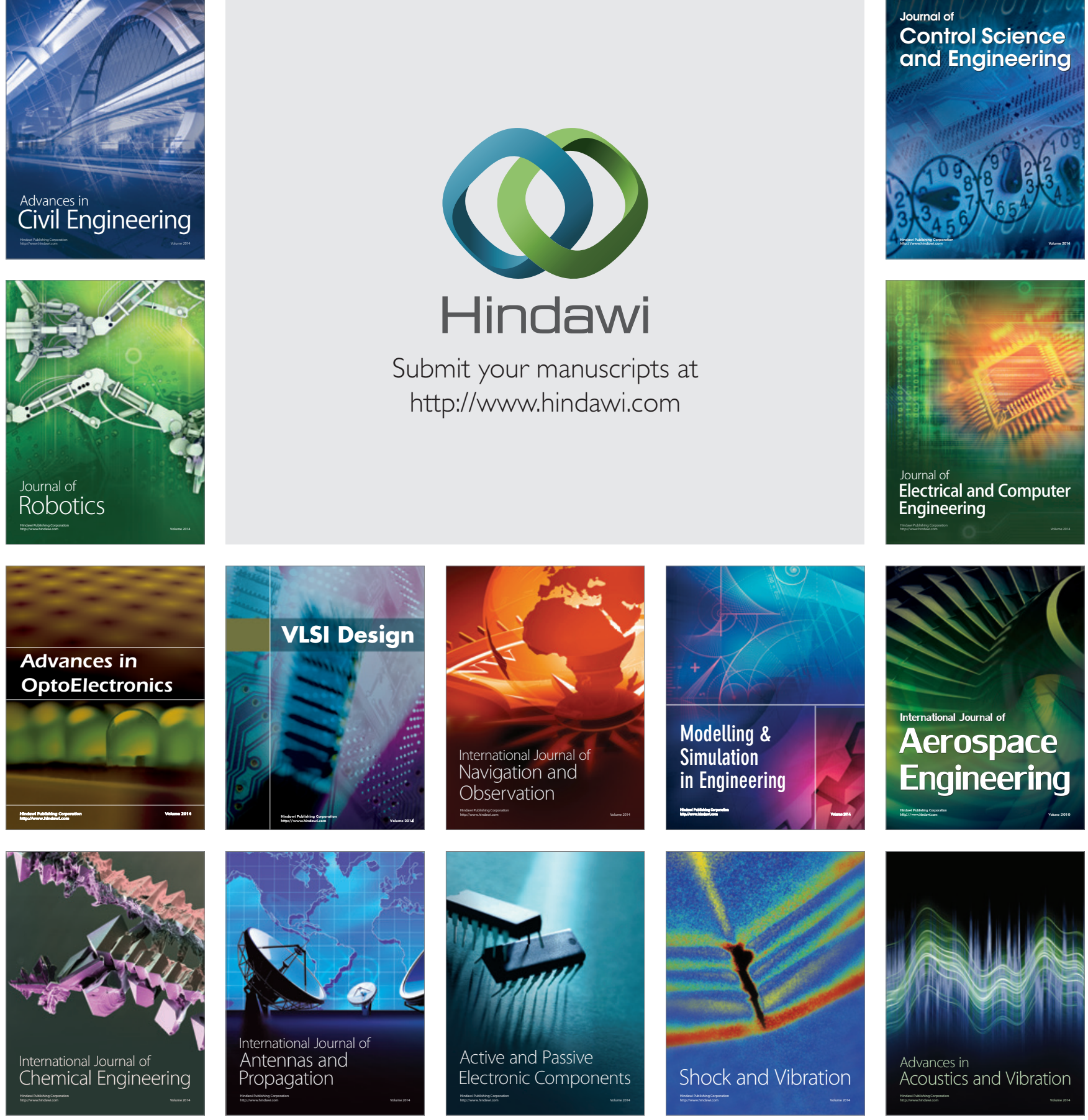